\title{
Sejarah Teori Peluang dan Statistika
}

\author{
Bambang Sri Anggoro \\ IAIN Raden Intan Lampung; Bambang@radenintan.ac.cid \\ Submitted : 06-04-2015, Revised : 16-04-2015, Accepted : 20-05-2015
}

\begin{abstract}
Opportunity theory is a branch of mathematics concerned withopportunities, analysis of ran dom phenomena. The main objects ofopportunity theory are random variables, stochasticpr ocesses, andevents : a nondeterministic mathematical abstraction of measurableevents or $q$ uantities that can be singleevents or develop over time inseemingly random modes. If indivi dual coins toss or dice rollsareconsidered random events, then if repeated sequences of rand omevents will show certain patterns, which can be learned and predicted.

Two representative mathematical results illustrate such patterns are large number law and central limit theorem. As a mathematical basis for statistics, probability theory is important for many human activities involving quantitative analysis of large sets of data. The method of opportunity theory also applies to complex system descriptions given only partial knowledge of their country, as in statistical mechanics. A great discovery of twentiethcentury physics is the nature of probability of physical phenomena on an atomic scale, described in quantum mechanics.
\end{abstract}

Keyword: Opportunity; Statistics.

\begin{abstract}
Abstrak
Teori peluang adalah cabang matematika yang bersangkutan dengan peluang, analisis fenomena acak. Obyek utama teori peluang adalah variabel acak, proses stokastik, dan kejadian: abstraksi matematis non-deterministik peristiwa atau kuantitas terukur yang dapat berupa kejadian tunggal atau berkembang dari waktu ke waktu dalam mode tampaknya acak. Jika koin individu melemparkan atau gulungan dadu dianggap peristiwa acak, maka jika berkali-kali mengulangi urutan kejadian acak akan menunjukkan pola-pola tertentu, yang dapat dipelajari dan diprediksi. Dua hasil matematis representatif menggambarkan pola tersebut adalah hukum bilangan besar dan teorema limit pusat.Sebagai dasar matematika untuk statistik, teori peluang adalah penting untuk kegiatan manusia banyak yang melibatkan analisis kuantitatif set besar data. Metode teori peluang juga berlaku untuk deskripsi sistem yang kompleks diberikan pengetahuan hanya sebagian dari negara mereka, seperti dalam mekanika statistik. Sebuah penemuan besarfisika abad kedua puluh adalah sifat peluang fenomena fisik pada skala atom, dijelaskan dalam mekanika kuantum.
\end{abstract}

Kata Kunci: Peluang; Statistika.

\section{PENDAHULUAN}

\section{Sejarah Teori Peluang}

Teori Peluang yang merupakan cabang Matematika, menitikberatkan perhatian pada analisis gejala-gejala random. Objek-objek utama Teori Peluang adalah variabel-variabel 
random, proses-proses stokastik, dan kejadian-kejadian (abstraksi matematika dari kejadian non deterministik). Dalam kehidupan sehari-hari, kita sering mendengar istilah 'acak' atau 'random'. Kita sering merasa kita sudah paham dengan maksud 'acak' tersebut. Akan tetapi ide tentang keacakan itu sendiri merupakan salah satu hal yang terabaikan. Bagaimana kita dapat membentuk pola-pola acak? Bagaimana kita dapat mengenal pola-pola acak pada saat kita dikonfrontasikan dengan pola-pola tersebut?

Ide utama tentang keacakan ini adalah ide tentang 'unpredictability'. Sebuah pola acak sering digambarkan sebagai sesuatu yang tidak bisa diprediksi. Sebenarnya, sudah berapa lamakah penelitian mengenai pola-pola acak ini? Para arkeologi sudah menemukan bukti-bukti prasejarah yang muncul dan dapat dibandingkan dengan permainan dadu saat ini. Gigitan pada tulang dan keratan pada batu-batu secara jelas diciptakan atau diletakkan di satu sisi untuk sebuah maksud. Objek-objek ini, menurut bukti, memiliki makna bagi pemakai dan menyerupai objek yang terakhir digunakan dalam permainan papan oleh, misalnya, masyarakat Mesir kuno. Bukti-bukti ini sulit diinterpretasikan. Tanpa catatan tertulis, sangat sulit menemukan makna penemuan-penemuan tersebut untuk pemakai.

Satu dari alat-alat pertama yang memproduksi pola-pola acak adalah astragalus. Astragalus adalah sebuah tulang yang terdapat pada tumit rusa, biri-biri, anjing dan mamalia lainnya. Banyak astragalus yang ditemukan pada zaman prasejarah. Hal ini berarti, benda ini sudah digunakan sejak 5000 tahun yang lalu, di zaman Mesir kuno dalam permainan kesempatan (peluang). Terdapat gambar-gambar masyarakat Mesir kuno yang melambunglambungkan astragalus saat bermain permainan papan. Sayangnya, tidak ada catatan bagaimana memainkan permainan ini dan bagaimana pola-pola hasil lambungan astragalusastragalus tersebut. Gambar di bawah ini merupakan bukti prasejrah mengenai adanya permainan tersebut.

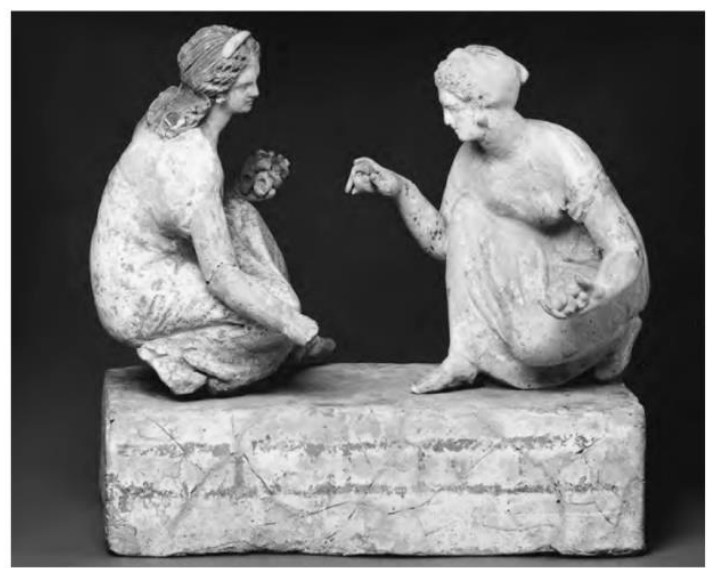

Gambar 1. Pemain-pemain tulang astralagus

Permainan pertama mengenai peluang yang dapat dipahami dengan baik adalah yang berasal dari Mesopotamia. Salah satu kota penting di Mesopotamia saat itu adalah Ur. Saat melakukan penggalian di awal abad 20, para arkeolog menemukan sebuah permainan papan yang tertimbun dengan pemakainya. Permainan papan dengan pahatan yang bagus tersebut sudah berusia sekitar 4500 tahun. Permainan ini dapat diphami dengan baik krena catatan kuno mengenainya juga diperoleh dari penggalian. Permainan ini dinamakan Permainan dari 20 Persegi. Pemainnya terdiri dari dua orang. Masing-masing percaya pada 
sebuah kombinasi keberuntungan dan sebuah strategi kecil untuk menang. Pada bagian keberuntungan, dilambungkan sebuah dadu untuk menentukan berapa banyak persegi untuk setiap pemain agar dapat menggerakkan bagiannya. Keterampilan yang harus dimiliki adalah memilih bagian yang harus digerakkan.

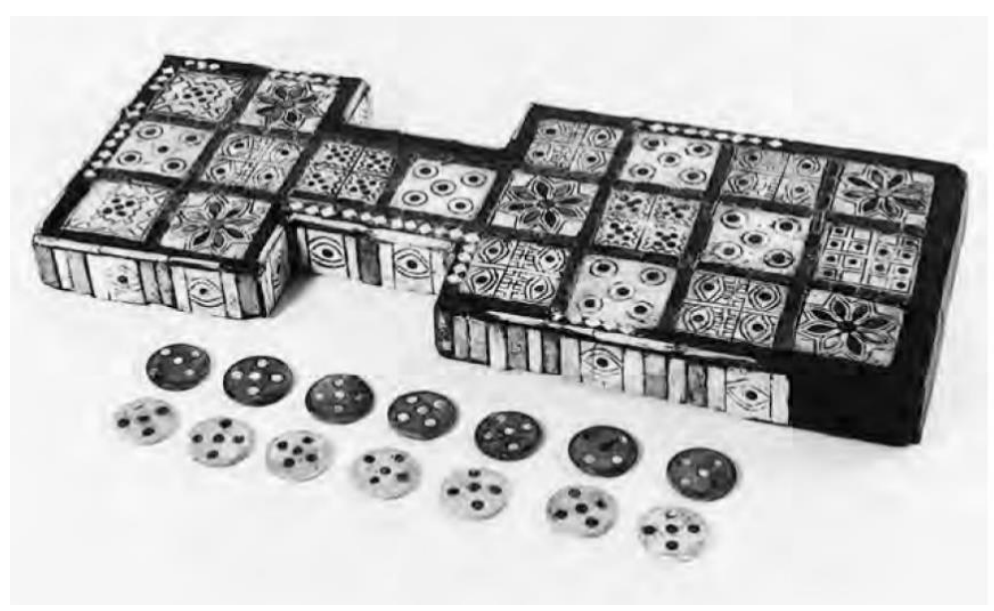

Permainan di atas menunjukkan adanya proses acak karena banyaknya bagian yang dapat dilompati setiap pemain ditentukan oleh hasil lambungan sebuah dadu. Permainan ini terkenal smpai Mesir dan India. 250 tahun setelah penemuan Permainan 20 Persegi, budaya Mesopotamia semakin berkurang pengaruhnya. Yang paling dominan saat itu adalah budaya Romawi dengan permainan judinya. Judi dapat dianggap sebagai permainan papan tanpa papan. Keterampilan pemain diabaikan dan peserta hanya bertaruh untuk hasil lambungan astragalus yang keluar. Raja Agustus dan Vitellius dikenal sebagai raja-raja yang gila judi.

\section{Galileo Galilei (1565-1642)}

Galileo Galilei merupakan ilmuwan yang masyur sepanjang zaman. Observasi-observasi astronominya khususnya planet Venus, matahari, dan planet Jupiter telah membuktikan secara gemilang bahwa bumi bukanlah pusat jagat raya. Galileo merupakan satu dari ilmuwan-ilmuwan pertama yang mengembangkan fisika dengan menggunakan sebuah kombinasi antara rancangan percobaan yang hati-hati dengan analisis matematika yang seksama. Dalam artikelnya yang berjudul "Thoughts about Dice-Games" ia juga menulis sedikit tentang keacakan. 


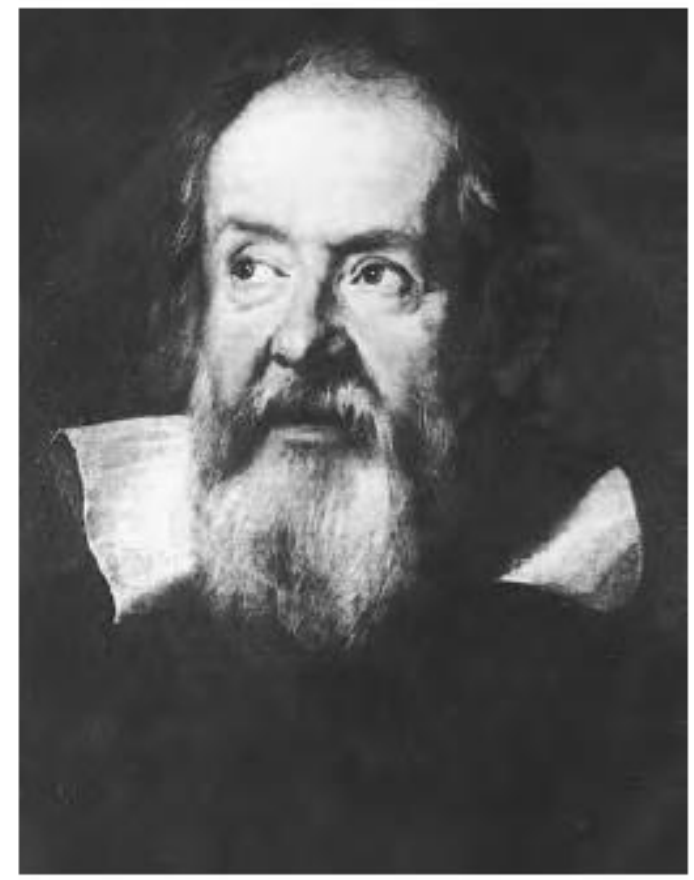

Galileo Galilei

Observasi-observasi Galileo mengenai dadu tidaklah terkenal. Bahkan Galileo sendiri tidak cukup menaruh perhatian pada permainan tersebut. la menyebutkan di awal paragraf artikelnya di atas, bahwa ia menulis tentang dadu karena mendapat giliran untuk melakukannya (tidak dijelaskan Galileo siapa yang menyuruhnya tersebut). Tampaknya Galileo menjadi orang pertama yang membicarakan keacakan secara matematika (Galileo masih kecil saat Cardano hidup). Pada saat ini artikel kecilnya tersebut menjadi pendahuluan yang baik untuk Teori Peluang sederhana.

Dalam artikelnya tersebut Galileo menanyakan, mengapa dari pelambungan tiga dadu jumlah 10 dan 11 lebih sering muncul dibandingkan 9 dan 12. Penyelesaiannya merupakan materi berhitung sederhana. la memulai dengan menunjukkan bahwa hanya ada 16 jumlahan yang berbeda yang muncul dari pelambungan tiga dadu, yaitu $3,4, \ldots, 18$. Ketiga dadu tersebut identik kecuali warna. Jumlah 3 diperoleh dengan satu cara, jumlah 4 dengan tiga cara, dan seterusnya. Galileo menunjukkan ada 27 cara mendapatkan jumlah 10 dan 25 cara untuk mendapatkan jumlah 9. Secara keseluruhan terdapat 216 cara untuk untuk mendapatkan jumlah 3 sampai dengan 18. 216 cara tersebut diperoleh dari $6 \times 6 \times 6$, yaitu 6 angka dari dadu I, 6 angka dari dadu II, dan 6 angka dari dadu III.

Galileo tidak melanjutkan penemuannya ke konsep Peluang. Meskipun demikian tulisan Galileo tersebut merupakan acuan awal peluang yang dikerjakan secara matematika. Hal ini dapat menjadi pelajaran, bahwa tak seorangpun saat itu, termasuk Galileo sendiri, yang menyadari bahwa suatu kajian yang sederhana pada akhirnya dapat menjadi awal sebuah teori besar. 


\section{Pierre de Fermat (1601-1665) dan Blaise Pascal (1623-1662)}

Pierre de Fermat dan Blaise Pascal merupakan ilmuwan-ilmuwan Perancis yang terkenal. Keduanya banyak membuat banyak penemuan dalam sebuah disiplin matematika. Keduanya merupakan penggemar-penggemar matematika yang brilian.

Fermat yang 22 tahun lebih tua dari Pascal, pada awlnya dikenal sebagai praktisi hukum. Akan tetapi di waktu-waktu luangnya, ia banyak belajar matematika dan bahasa. la menguasai bahasa Yunani, Latin, Spanyol, Itali, dan tentu saja Perancis. Untuk membuat pikirannya tetap segar, Fermat justru lebih suka mendapatkannya dengan melakukan korespondensi dengan para matematikawan terbaik. Banyak dari surat-suratnya tersebut yang menunjukkan keseriusannya dalam mencari kebenaran matematika.

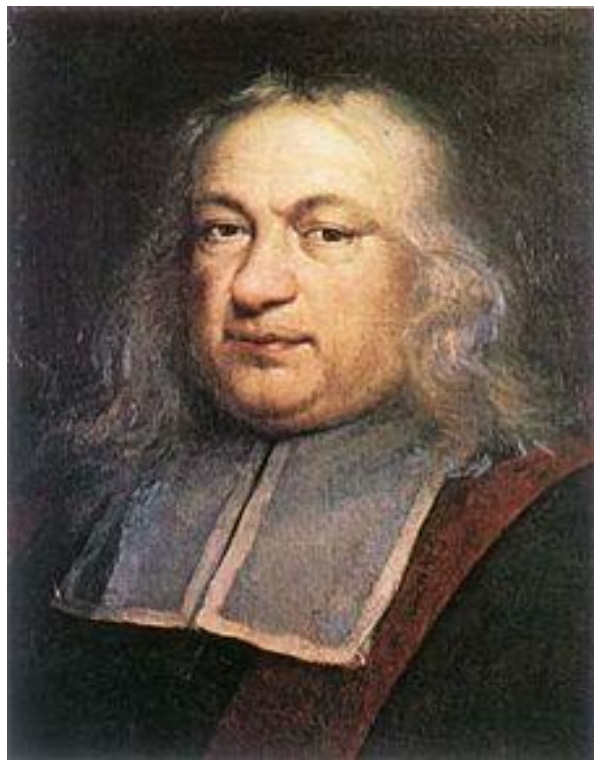

Pierre de Fermat

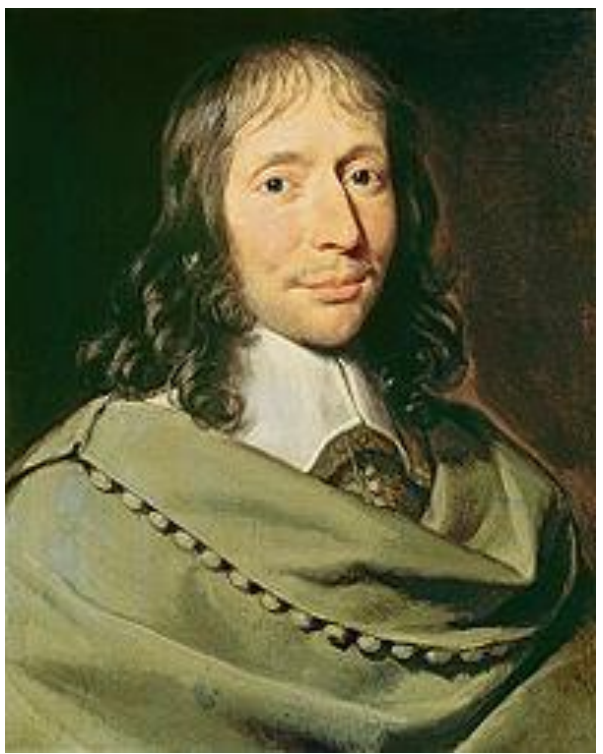

Blaise Pascal

Berbeda dengan Fermat, Blaise Pascal menghabiskan masa-masa remajanya untuk mempelajari matematika melalui tatap muka langsung dengan ahli-ahli matematika terbaik dalam sebuah klub matematika terkenal, Marsenne Academy (Marsenne adalah seorang pendeta Perancis yang mencintai sains, matematika, dan musik). Fermat bukan anggota di klub itu, hanya sesekali mengunjunginya. Akan tetapi, salah satu anggotanya adalah seorang ahli matematika Perancis, Etienne Pascal, yang saat ini lebih dikenal sebagai ayah dari Blaise Pascal.

Blaise Pascal mulai belajar geometri dari ayahnya saat berusia 12 tahun. Ketika ia berusia 14 tahun ia mulai sering menemani ayahnya ke klub matematika. Kunjungan-kunjungannya ke klub tersebut semakin membuka cakrawala berpikir Blaise. Pada usia 16 tahun ia secara gemilang melakukan penemuan penting dalam geometri proyeksi. Akan tetapi perhatian Pascal muda berubah begitu cepat. Saat berusia 18 tahun ia berhenti belajar geometri dan 
beralih menjadi mekanik kalkulator. Walaupun kurang dapat dipercaya dan agak mahal, akan tetapi Pascal berhasil melakukan beberapa penjualan. Kalkulator-kalkulator ini memuat ide-ide besar Pascal yang diadopsi banyak perusahaan kalkulator untuk desain mereka.

Ketika dewasa. Pascal diperkenalkan dengan seorang nobelis Perancis, Chevalier de Mere, yang juga seorang penjudi. Pascal dan de Mere banyak berdiskusi mengenai dasar-dasar matematika yang terkait judi. Pada tahun 1654 Chevalier de Mere menemukan sistem penjudian. Ketika Chevalier kalah dalam berjudi dia meminta Blaise Pascal menganalisis sistim perjudiannya. Saat itulah Fermat dan Pascal mulai melakukan kegiatan surat menyurat terkenal mengenai persoalan-persoalan dalam permainan judi ini yang dikaji secara matematika dan menemukan bahwa sistim yang dipunyai oleh Chevalier akan mengakibatkan peluang dia kalah $51 \%$. Pascal menulis salah satu topik yang dilontarkan oleh de Mere yang dikenal dengan problème des partis (problem of points),Pascal menemukan solusi masalah tersebut yang diistilahkan dengan Aleae Geometriayang dijelaskan di Académie Parisienne. Pascal menuliskan teori Traité $d u$ Triangle Arithmétiqueyang dipublikasikan pada tahun 1665.

\section{Jacob Bernoully (1654-1705)}

Matematikawan dan filsuf Jerman Gottfried Leibniz (1646-1716) beserta matematikawan dan fisikawan Inggris melanjutkan penemuan-penemuan Fermat dalam kalkulus secara independen. Dampak kalkulus dalam matematika tidak bisa dibendung. Banyak masalah matematika yang pada awalnya dianggap sulit, saat ini menjadi sesuatu yang mudah diselesaikan. Teori Peluang pun mendapat keuntungan dari ide-ide dan tekhnik-tekhnik baru dalam kalkulus.

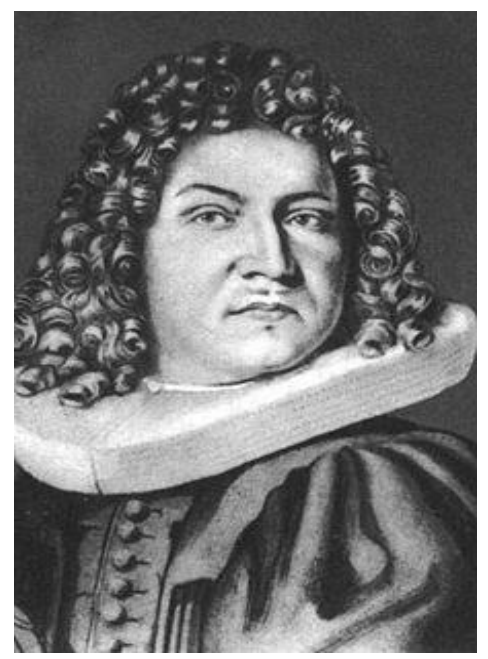

Jacob Bernoulli

Matematikawan Swiss, Jacob Bernoully, merupakan matematikawan pertama yang memperkenalkan pentingnya kalkulus dalam peluang sebagaimana pentingnya peluang dalam dunia judi. Pada awalnya, Jacob Bernoully dididik untuk menjadi menteri. Akan tetapi menjadi menteri itu ternyata lebih merupakan pilihan ayahnya, bukan dirinya sendiri. Di lain 


\section{Al-Jabar: Jurnal Pendidikan Matematika \\ Vol. 6, No. 1, 2015, Hal 13 - 24}

pihak, ia lebih suka mempelajari astronomi dan matematika. Sebagai anak yang baik, ia tetap mentaati permintaan ayahnya tersebut. Perjalanan pertamanya mengelilingi Eropa Utara mempertemukannya dengan matematikawan dan ilmuwan besar. la merombak banyak ide dan belajar sebanyak yang ia mampu. Pada usia 27 tahun ia kembali ke Swis dan memulai hidup barunya sebagai guru matematika.

Bernoully berkorespondensi dengan Leibniz selama beberapa tahun dan membangun sebuah minat baru dalam peluang. la sangat terkesan oleh buku Christian Huygens, De ratiociniis in Ludo Aleae. la sendiri banyak menuangkan ide mengenai peluang dalam bukunya Ars Conjectandi. Buku itu hampir selesai saat ia meninggal. Saudara sepupu Jacob Bernoully, Nicolas, menyelesaikan bagian akhir buku tersebut setelah lama tertunda. Buku itu sendiri baru dipublikasikan pada tahun 1713 setelah 8 tahun kematian Jacob Bernoully dan terdiri atas empat bagian yaitu:

a. Tractatum Hugenii De Ratiociniis in Ludo Aleae, Cum Annotationibus Jacobi Bernoullj. (Sebuah catatan tambahan dari De Ratiociniis in Ludo Aleae)

b. Doctrinam de Permutationibus \& Combinationibus (la membuktikan hukum binomium Newton)

c. Usum Praecedentis Doctrinae in variis Sortitionibus \& Ludis Aleae (la mengaplikasikan elemen-elemen bab II untuk pertanyaan-pertanyaan peluang)

d. Usum \& Applicationem Praecedentis Doctrinae in Civilibus, Moralibus \& Oeconomicis (la mengembangkan the (weak) law of large numbers).

Perhitungan-perhitungan dalam Ars Conjectandi masih di seputar permainan judi. Akan tetapi dalam buku tersebut, Bernoully mulai menjauhkan Teori Peluang dari dunia perjudian. Sebagai contoh, ia memikirkan berapa peluang yang muncul untuk masalahmasalah dalam hukum kriminal dan kematian manusia. la tidak melakukan banyak kemajuan untuk satu hal ini akan tetapi ia secara signifikan telah memperkenalkan Teori Peluang yang membantu kita memahami sebuah variasi dari area pengalaman manusia.

Sebuah teori dalam Ars Conjectandi, The Law Of Large Number, sering dinamakan juga dengan nama Teorema Bernoully. Penemuan ini menjadi perdebatan para matematikawa dan filsuf selama seabad setelah publikasi pertama Ars Conjectandi. Dalam teori ini Bernoully memikirkan sebuah himpunan kejadian-kejadian acak yang saling independen. Dalam Teori Peluang, dua buah kejadian dikatakan saling independen jika munculnya sebuah kejadian tidak mempengaruhi munculnya kejadian lain. Selanjutnya, Bernoully memikirkan sebuah rasio antara jumlah kemunculan suatu kejadian dengan seluruh jumlah eksperimen yang kemudian dikenal dengan istilah peluang. Penemuan-penemuan Bernoully ini merupakan karya berharga dalam Teori Peluang.

\section{Edmond Halley (1656-1742)}

Nama Edmond Halley lebih dikenal karena Komet Halley. la bukan orang pertama yang meneliti komet ini, akan tetapi ia orang pertama yang memprediksi kemunculan ulangnya. la mempelajari catatan-catatan dari sejumlah komet dan membentuk opini bahwa satu dari komet-komet tersebut muncul secara periodik. Pada tahun 1705 ia mempublikasikan hasil-hasil perhitungannya dalam Synopsis on Cometary Astronomy yang mengatakan bahwa komet yang muncul di tahun 1531, 1607, dan 1682 adalah komet yang 
sama. Komet itu melintasi bumi dalam sebuah lintasan sekitar 76 tahun sekali. la memprediksi bahwa komet tersebut akan muncul kembali di tahun 1758 . Walaupun pada akhirnya Halley meninggal sebelum 1758, akan tetapi dunia sudah membuktikan bahwa ramalannya tepat. Komet itu muncul tepat di hari Natal pada tahun 1758 . Komet itu kemudian dinamakan Komet Halley. Tercatat dalam sejarah, bahwa penulis terkenal Mark Twain lahir dan meninggal pada tahun-tahun kemunculan Komet Halley, yaitu tahun 1835 dan 1910.

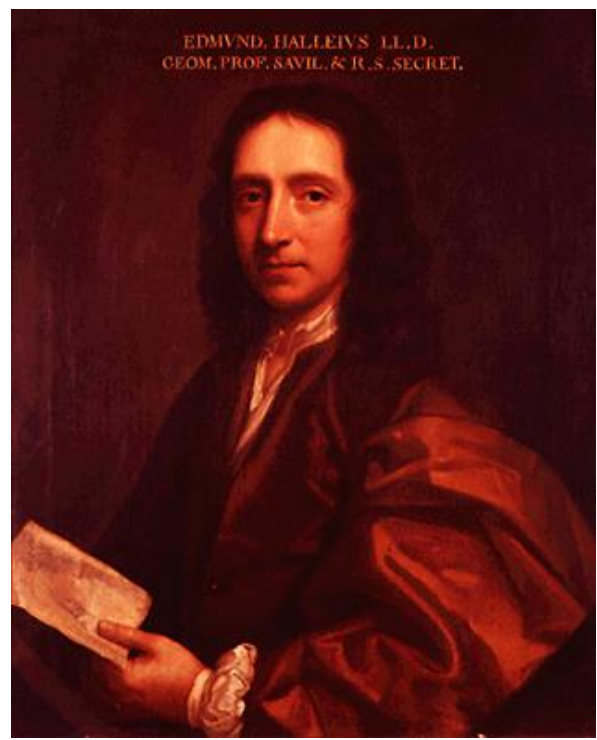

Edmond Halley

Halley dilahirkan dalam keluarga yang kaya dan pada saat itu ketertarikan masyarakat pada dunia sains dan matematika sangatlah tinggi. Edmond Halley pun mulai tertarik pada matematika dan astronomy di usianya yang masih sangat muda. Orang tuanya yang kaya raya tersebut memenuhi hasrat anaknya dengan membelikan berbagai macam perlengkapan astronomi. Halley pun menjadi terbiasa dan mahir menggunakan alat-alat tersebut. Ketika ia masuk Queen's Colledge, Oxford, untuk memulai studinya, ia mendapatkan cukup peralatan untuk memulai penelitiannya sendiri.

Saat Halley di Queen's Colledge, ia sempat mengunjungi Royal Greenwitch Observatory, sebuah tempat yang memberikan kedudukan penting untuk para ilmuwan. la menemui kepala observatori, John Flamsteed, seorang ilmuwan penting saat itu. Dari pertemuan tersebut Halley berhasrat besar untuk membuat penelitian yang lebih tinggi. la meninggalkan Queen's Colledge sebelum lulus dan membawa sejumlah perlengkapan astronomi bermutu tinggi ke pulau vulkanik di Saint Helena, yang terletak 1000 mil dari pantai Afrika, di Lautan Atlantik Utara. Sekali waktu, Halley menetapkan sendiri observasinya secara temporer di pulau tersebut.

Halley memilih pulau itu karena berlokasi tepat di selatan equator. Bintang-bintang yang tampat di Saint Helena tampak berbeda dengan bintang-bintang yang tampak di Greenwitch. Tujuan penelitiannya adalah untuk membuat chart bintang di Hemisphere Selatan sebagai pelengkap dari yang sudah dilakukan Flamsteed di Hemisphere Utara. Meskipun pekerjaannya diganggu malam-malam yang berawan, Halley berhasil membuat pengukuran-pengukuran yang akurat untuk lebih dari 300 bintang. Pekerjaan Halley ini 
patut dicontoh. Pada akhirnya Halley dianugerahi gelar Master dari Queen's Colledge atas perintah Raja Charles II. Tulisan Halley ini memberikan kontribusi yang besar dalam perkembangan statistika. Meskipun belum menghasilkan sebuah teori, akan tetapi Halley sudah menunjukkan pekerjaan secara statistika.

\section{Johann Carl Friedrich Gauss (1777-1855)}

Johan Carl Friedrich Gauss dilahirkan di Braunchweig, Jerman sebagai putra tunggal seorang buruh miskin. Pada usia tiga tahun, ia secara tepat menghitung tanpa kesalahan secara mental kekeliruan dalam perhitungan yang dilakukan ayahnya dalam sebuah tulisan mengenai kekayaan. Cerita terkenal lainnya adalah ketika ia duduk di bangku sekolah dasar. Saat itu gurunya, JG Buttner, hendak menenangkan murid-muridnya dengan menyuruh mereka menghitung jumlah bilangan bulat dari 1 sampai 100. Gauss menyelesaikan pekerjaannya dalam hitungan detik. Pekerjaannya ini, yang dalam aritmatika dikenal dengan jumlah deret bilangan, sangat mengejutkan guru dan asistennya, Martin Bartels. Ayahnya menginginkan Gauss mengikuti jejaknya menjadi tukang batu. la tidak mensuport keinginan Gauss untuk melanjutkan sekolah mempelajari matematika dan sains. Akan tetapi, ia didukung penuh oleh ibunya. Dengan usaha keras dan bantuan Duke of Braunchweig yang menghargai Gauss dengan beasiswa ke Collegium Carolinum, akhirnya Gauss berhasil melanjutkan pendidikannya. Gauss mempelajari matematika di University of Gottingen (1795-1799) dan berhasil meraih gelar doktornya dari University of Helmstedt di tahun 1799. Pada akhirnya, ia menjadi akademisi di University of Gottingen.

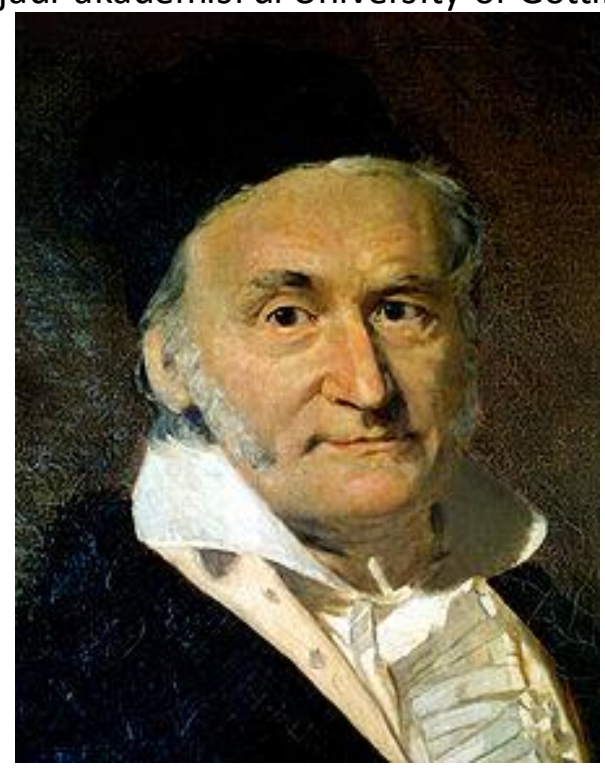

Johan Carl Friedrich Gauss

Gauss memiliki keyakinan untuk mempublikasikan tulisan-tulisannya yang sudah layak. la tidak terbiasa mempublikasikan hasil-hasil pemikirannya sesegera mungkin. Oleh sebab itu, ketika ada ilmuwan yang menemukan sesuatu yang baru, Gauss sering mengklaim bahwa ia sudah menemukan hal tersebut terlebih dahulu. la pun mengklaim bahwa ialah yang menemukan terlebih dahulu sesuatu yang ditemukan Legendre. Legendre mendeskripsikan Metode Kuadrat Terkecil di tahun 1805. sementara ia sudah menggunakannya di tahun 1795 . Saat itu ia tengah melakukan penelitian dalam bidang 
astronomy yang di dalamnya menggunakan kaidah Metode Kuadrat Terkecil. Gauss sendiri membuktikan teorema ini di bawah asumsi distribusi normal pada tahun 1809. Penemuan Gauss yang penting mengenai distribusi normal merupakan sejarah dalam statistika. Sejak penemuannya tersebut penggunaan distribusi normal menjadi sesuatu yang vital dalam statistika. Sebagai penghargaan kepadanya, acap kali distribusi tersebut dinamakan distribusi Gauss.

\section{Ronald Aylmer Fisher (1890-1962)}

Jika ada orang lain selain Pearson yang memberikan kontribusi penting untuk perkembangan statistika modern, maka dialah Ronald Aylmer Fisher, seorang statistikawan Inggris. Fisher dilahirkan di London, Inggris. la memiliki masa kecil yang indah. Meskipun penglihatannya kurang baik, ia merupakan siswa yang matang sebelum waktunya dengan memenangkan Medali Neeld (sebuah kompetisi essay dalam matematika) pada usia 16 tahun. Oleh karena penglihatannya yang buruk itu juga ia diajar matematika tanpa bantuan buku dan pena. la mengembangkan kemampuannya memvisualisasikan masalah-masalah geometri dengan menggunakan manipulasi-manipulasi aljabar. la juga sangat menyukai biologi, terutama evolusi.

Tahun 1909 Fisher memenangkan beasiswa untuk masuk Gonville and Caius Colledge, Cambridge. la lulus dari Cambridge University pada tahun 1912 dalam bidang astronomi. Ada kemungkinan dari bidang inilah muncul ketertarikannya pada statistika. Para astronom umumnya membuat banyak pengukuran dan kemudian menggunakan ide-ide dan tekhnik-tekhnik statistika untuk menginterpretasikan pengukuran-pengukuran mereka. Satu dari buku-buku yang pernah dibaca Fisher saat di Cambridge adalah Theory of Errors yang ditulis George Biddel Airy, seorang astronom Inggris terkenal. Sejak saat itu, Fisher tidak lagi bekerja sebagai astronom.

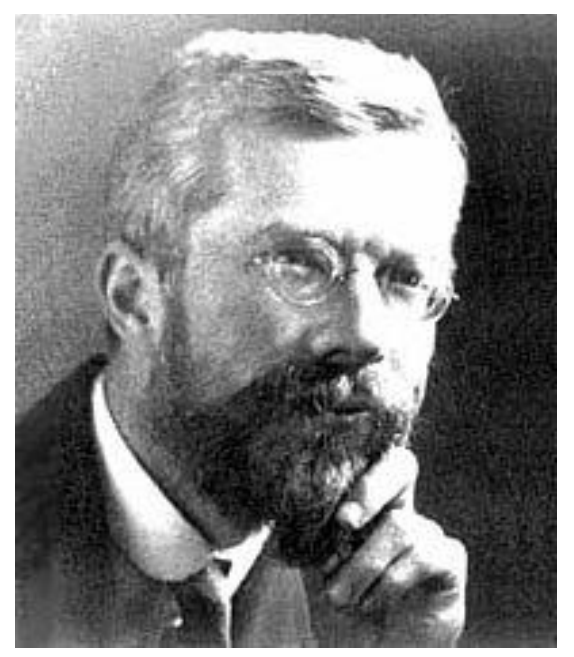

\section{R.A. Fisher}

Setelah lulus, Fisher mendapat kesulitan dalam masalah keuangan. Saat itu ia memutuskan bekerja di sebuah peternakan di Kanada selama beberapa bulan. Setelah kembali ke London, ia bekerja sebagai statistikawan di Mercantile and General Investment Company. Saat pecah Perang Dunia I (1914), ia berhasrat sekali untuk menjadi tentara. Akan 
tetapi karena penglihatannya yang buruk, ia ditolak. Akhirnya ia menjadi guru matematika dan fisika antara 1915 sampai 1919. Pada akhirnya Fisher memutuskan untuk bekerja penuh sebagai saintis karena mendapat dua tawaran bersamaan. Tawaran pertama dari Karl Pearson, yang sudah lebih dahulu terkenal, dan yang kedua dari Rothamsted Agriculture Experiment Station. Fisher memilih tawaran kedua dan di sana ia memberi kontribusi penting dalam statistika terutama dalam desain dan analisis eksperimen. Fisher mempelajari desain berbagai eksperimen dengan terlebih dahulu membuat konsep randomisasi dan analisis varians.

Pada tahun 1912, ia memperkenalkan konsep Maximum Likelihood. Sedangkan pada tahun 1922, ia memberi definisi baru tentang statistika. Tujuannya adalah untuk mengurangi data (pada saat itu semua statistikawan dan ilmuwan selalu melibatkan data yang besar dalam penelitian-penelitian mereka). la mengidentifikasikan tiga masalah mendasar, yaitu: karakteristik populasi yang diamati, estimasi, dan distribusi.

Fisher mempublikasikan buku Statistical Methods for Research Workers pada tahun 1925 yang merupakan buku terlaris sepanjang masa. Buku ini dicetak ulang selama lebih dari 50 tahun. Fisher pun mempublikasikan buku The Design of Experiments (1935) dan Statistical Table (1947). Semuanya ini memberikan kontribusi penting dalam perkembangan statistika modern

\section{DAFTAR PUSTAKA}

Anglin W, S. (1994). Mathematics: A Concise History and Philosophy. Springer Verlag. Boyer, C,. (1968). History of Mathematics. Jhon Wiley \& Son

Tabak, J. (2004). Probability and Statistics. The Science and Uncertainty. New York: Facts On File.

http://en.wikipedia.org/wiki/Gerolamo Cardano

http://www.stetson.edu/ efriedma/periodictable/html/Cd.html

http://en.wikipedia.org/wiki/Galileo Galilei

http://en.wikipedia.org/wiki/Pierre_de_Fermat

http://en.wikipedia.org/wiki/Blaise Pascal

http://en.wikipedia.org/wiki/Christian Huygens

http://en.wikipedia.org/wiki/Jacob Bernoulli

http://en.wikipedia.org/wiki/Abraham de Moivre

http://en.wikipedia.org/wiki/Thomas Bayes

http://en.wikipedia.org/wiki/Pierre-Simon_Laplace

http://www-history.mcs.st-andrews.ac.uk/Biographies/Poisson.html

http://id.wikipedia.org/wiki/Revolusi Perancis\#Sejarah

http://www.answers.com/topic/john-graunt

http://www.ac.wwu.edu/ stephan/Graunt/grauntbio.html

http://en.wikipedia.org/wiki/Edmund Halley

http://www.answers.com/topic/edmond-halley

http://www.maths.tcd.ie/pub/HistMath/People/Legendre/RouseBall/RB Legendre.html

http://en.wikipedia.org/wiki/Carl Friedrich_Gauss 


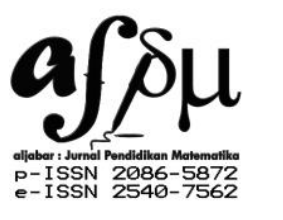

Al-Jabar: Jurnal Pendidikan Matematika

Vol. 6, No. 1, 2015, Hal 13 - 24

http://en.wikipedia.org/wiki/Karl Pearson

http://www.answers.com/topic/karl-pearson

http://en.wikipedia.org/wiki/Ronald_Fisher

http://www-groups.dcs.st-and.ac.uk/ history/Biographies/Fisher.html 